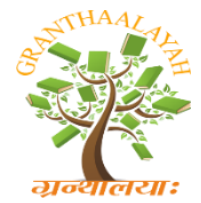

INTERNATIONAL JOURNAL OF RESEARCH

GRANTHAALAYAH

A knowledge Repository

Management

\title{
CAPITALISM, CONSUMERISM AND POPULAR CULTURE
}

\author{
Ankita Singh *1 \\ ${ }^{* 1}$ Gargi College, University of Delhi, India
}

\begin{abstract}
A product's utility has evolved over time. In today's world, the commodities possess the power to define us. Every product that we own today, through its branding, reflects our social status, values and vice versa. It is difficult to refute the negative influence of capitalism that we witness in form of obsession with possession. The aim of the paper is to study the extent to which the products of the modern society like the protagonists in the following two movies suffer; whether it is possible to imagine an end of consumerism and not the world or has it become an inherent part of the late capitalist world in which there is no completeness but the perennial emergence of substitutes (objects). This paper studies the aforementioned issues through the movies "Fight Club" and "Confessions of a Shopaholic". The first section of the paper uses the case of soap industry as the foundation and analyses "Fight Club". The second section examines the role of credit card companies in compulsive buying disorder through "Confessions of a Shopaholic". Despite the similarity between the two movies on the grounds of the modern world "suffering", the paper highlights the difference in their treatment of the main theme of consumerism and links it to the gender politics. The final section draws a comparison between the endings of the two movies and investigates the premise of disorder in "Fight Club" and its existential threat to capitalism.
\end{abstract}

Keywords: Capitalism, Pop Culture; Consumerism; Soap Industry; Compulsive Buying Disorder; Gender Politics; Advertisements.

Cite This Article: Ankita Singh. (2018). "CAPITALISM, CONSUMERISM AND POPULAR CULTURE." International Journal of Research - Granthaalayah, 6(4), 205-210. https://doi.org/10.29121/granthaalayah.v6.i4.2018.1645.

\section{Introduction}

A product's utility has evolved over time. Every commodity that we own today not just reflects our social status and values but it also possesses the power to define us. It is difficult to refute the negative influence of capitalism that we witness in the form of obsession with possession. Moreover, credit card companies further help realise this desire by making "limitless" funds available. By taking the case of the soap industry, this paper studies how advertisements, with their clever strategies, have a major role to play in consumerism. Under the main theme of consumerism, the sub-theme that this paper touches upon is that of gender and its relation with consumerism as depicted in popular culture. The paper also attempts to link these issues and analyse two movies, 
Fight Club and Confessions of a Shopaholic. The final section draws a comparison between the endings of the two movies and investigates the anarchist (or anti-capitalist) perspective in Fight Club.

\section{Discussion}

The power of advertising is such that it can create a demand where none exists, of a commodity which is not needed. The soap industry is one of the best examples to understand the potential of this tool that has been used by capitalists to expand their businesses since times when there was no electronic media. Sensitivity towards sanitization is a recent phenomenon and of course, not without any implication of profit earning. Why do we have tens of companies manufacturing one product which has one basic utility that of cleansing? The advertisements target different aspects of their products. In the case of soaps, germs can only be killed by Lifebuoy, smooth skin can only be achieved by using Dove, and celebrity like beauty can only be attained by using Lux. The irony lies in the fact that all these brands mentioned belong to the same company, HUL (Unilever, India) - the umbrella organisation which is responsible for pulling the strings. These brands are advertised in a way that a false sense of competition is created and these "artificially diversified" (Baudrillard 88 ) products then govern the consumption.

Soap production for personal care began ever since "cleaning the body and its clothing had come under public scrutiny in the late nineteenth century as part of the campaigns of various social movements" (Stephen 59) ${ }^{1}$. Today, more than a century later, this need for personal hygiene has found its connection with the idea of beauty. Advertisements of both laundry and beauty soap idealise whiteness as the indicator of hygiene and beauty. James Corbett acknowledges that "Personal hygiene, closely linked with the idea of beauty, is a social construction that regulates the behaviour of the society" (54). The manufacturers, in turn, manipulate their advertisements based on our acceptance and conformity to the idea of cleanliness that comes from whiteness ${ }^{2}$. They engage with our "vanity, a social concern with appearances, by offering for comparison two objects, one of which is whiter than the other" (Barthes 36).

Director David Fincher's Fight Club (1999) tries to destabilise all the ideas that are sold to us along with all types of advertisements - the idea of how to live life, of how to be a perfect employee, how to dress up on different occasions and how to be a man or a woman. The unnamed protagonistnarrator suffers from Dissociative Identity Disorder (DID) and creates the Other, Tyler Durden, an identity that possesses everything the narrator otherwise lacks. The narrator is a regular whitecollar worker who despises his job, suffers from insomnia, lives alone in a condominium (condo), has no friends or family but has a house which is well furnished with all the latest IKEA (a leading, Swedish furniture company) home solutions. In the movie, he says, "Like so many others, I had become a slave to the IKEA nesting instinct... what kind of dining set defines me as a person?" (Fight Club). His condo becomes his identity such that when it gets destroyed, he says, "That condo was my life. I loved every stick of furniture in that place. That was not just a bunch of stuff

\footnotetext{
${ }^{1}$ For an interesting history of how soap industry created a niche in the market for a personal hygiene and beauty care product which was once laundry soap, see Stephen 60-67. It offers a feminist critique on how women have been targeted as consumers

${ }^{2}$ See Barthes 35-36 where he studies the difference between purifying liquids, soap-powders and detergents based on psychoanalysis
} 
that got destroyed. It was me" (Fight Club). Of course, what encouraged him to identify with the condo and its furniture was the IKEA catalogue, through which the company would sell the lifestyle solutions or in other words, sell the idea of how to own a lifestyle and what people should be aspiring for. Tyler tells how "we are by-products of a lifestyle obsession. Murder, crime, poverty, these things don't concern me. What concern me are celebrity magazines, TV with 500 channels, some guy's name on my underwear..." (Fight Club). Tyler helps him defy the concept of consumerist lifestyle by taking him from a condo to a dilapidated building where almost nothing works. The narrator then goes one step further by going to the office in a dishevelled appearance with soiled shirts and bruised face. He not only completely challenges the idea of cleanliness and whiteness that the advertisements sell, the idea of how one should be dressed, but also the white collared corporate culture.

The commodified forms of both femininity (long eyelashes, plump lips, spotless and glowing skin) and masculinity (facial hair, tall and buff body) sometimes unintentionally but mostly intentionally are sold through advertisements. In Fight Club, when the narrator notices a Gucci underwear advertisement showing a brawny model, he tells us, "I felt sorry for guys packed into gyms, trying to look like how Calvin Klein or Tommy Hilfiger said they should". He then asks Tyler, provoking a sneer, "Is that what a man looks like?". Two ideas that are invoked in this scene are: first, how like femininity, masculinity too is victimised by the patriarchal order and commodified in media culture. Second, why does one need designer underwear? In Tyler's terms, "Is this essential to our survival in the hunter-gatherer sense of the world?" (Fight Club). This is precisely what Baudrillard means when he writes, "All men are equal before objects as use-value, but they are by no means equal before objects as signs and differences, which are profoundly hierarchical" (89). Till the time we let the production sphere create this hierarchy among objects which have the same utility yet different values attached to them, we cannot hope to achieve the state of equilibrium.

As much as Fight Club attempts to question and shake up every single belief that has been internalised in this consumer world which conforms to the hierarchical order of objects, Director P.J. Hogan's Confessions of a Shopaholic (2009), on the other hand, seems to embrace and represent the same. The protagonist, Rebecca Bloomwood's (Becky) friend, Suze gasps when she sees that her friend has spent 200 dollars on a Marc Jacobs underwear, to which Becky innocently replies that "underwear is a basic human right". The concept of designer clothing has manipulated the consumer market so much that one often comes across posts on social media such as "Where do you see yourself in ten years?" followed by a picture of a girl, sitting in a luxurious room, surrounded with shopping bags from all the high-end designer stores. This is the idea of an ideal future that we are selling to the coming generations- a world further subsumed by consumerism. It is indeed debatable whether Hogan's movie is trying to appeal to our consumerist senses or is it plainly putting across how the facts are. However, this paper limits itself to the psychological issue of compulsive buying which arises from consumerism. Although it belongs to the genre of romantic comedy, the movie makes a mark because of its underlying theme of consumerism and debt. The character of Becky "...stirs up prickly issues about the complex interplay of women, fashion, spending and identity" (Colman).

Baudrillard acknowledges that "the pressure is exerted on women through the myth ${ }^{3}$ of Woman ... as [a] collective and cultural model of self-indulgence" (95). "ÉvelyneSullerot puts this well:

${ }^{3}$ For Myth, see Barthes 107-136 
Woman is sold to women ... while doing what she believes is preening herself, scenting herself, clothing herself, in a word 'creating' herself, she is, in fact, consuming herself' (qtd. in Baudrillard 95). The relationship between women, femininity and consumption is a popularly known and widely accepted one. The tradition of representing women as consumers and lovers of aesthetics is a long running one. Pope's Belinda in The Rape of the Lock (1712) and Flaubert's Emma Bovary in Madame Bovary (1857) ${ }^{4}$ could be considered as the inspiration behind a character like Rebecca's in the twenty-first century. While Belinda can be easily related to the high-class women who can afford to spend on luxuries like Carrie Bradshaw of Sex and the City series, Emma and Becky cannot- owing to their financially weaker background. How does then Becky manage to indulge herself in shopping from the most luxurious and expensive designer stores? The answer is provided to us at the beginning of the movie itself. As she is walking down the street, Becky gives us the details of how she has purchased her attire- "Jacket: VISA, dress- AMEX, belt- MasterCard, it is vintage and I got 1\% cash back, bag: Gucci and worth every penny!" (Confessions). Clearly, the "magic cards" that she saw as a child help her live her dream when she grows up. Becky is not the only one to have fallen into the trap of plastic money. The experiences of different people in Penaloza and Barnhart's research study on "normalisation of credit/debt" show us how credit cards have become essential for a smooth life in America- one is not eligible for certain services just because s/he does not have a credit card.

Moreover, the study shows that people "...blamed themselves and financial agents, explaining they had fallen for the 'easy' credit terms of 'predatory' lenders who punished them with high rates and fees" (Penazola and Barnhart 753). A common man can very well empathise when Becky in Confessions says, "They said I was a valued customer. Now they send me hate mail". She latercreates an analogy between a card and a coat and tells us how "...card is like a 50\% cashmere coat. The first time you meet, it promises to be your best friend until you look closely and realise it is not real cashmere. [You then realise that] you have been ripped off." Even though she feels duped, it is still difficult for her to put a constraint on her urge to shop because she is a compulsive buyer. In one of the scenes in Confessions, she tells herself that she does not need a scarf but as soon as she starts walking away, the mannequin draws her back saying, "Then again...who needs a scarf? Wrap some old jeans around your neck, that'll keep you warm... The point about this scarf is that it would become a part of a definition of your psyche." A study conducted by O'Guinn and Faber shows that compulsive buyers like Becky are obsessed with shopping because of certain personality traits like stronger imagination ${ }^{5}$ (which makes them prone to fantasising) and lower self-esteem than other common buyers. Becky explains her shopping experience as "the rush you feel when you swipe your card and it is approved and thenit all belongs to you. All you have to do is hand over a little card ... you feel so confident and alive ... and happy!" (Confessions).

The narrator in Fight Club is not a shopaholic but is shown as a "slave to the IKEA nesting instinct". Why and how are people like Becky and the unnamed narrator (the anonymity helps make it an everyman's story) so absorbed in the capitalistic driven consumer culture? Danielle

\footnotetext{
${ }^{4}$ Although not directly related to the capitalism we have in the $21^{\text {st }}$ century, their milieu does help one understand the continuous growth of the bourgeoisie, especially in the case of Madame Bovary. Flaubert's anti-bourgeoisie sentiments are visible throughout the text.

${ }^{5} \mathrm{O}$ 'Guinn and Barnhart's study proposes that consumers who are more prone to fantasizing get engrossed in their feelings and the shopping experience as a whole that they are unable to assess the reality of the situation and what the consequences of over indulgence could be. See O'Guinn and Barnhart 155 for the consequences.
} 
Todd, in his understanding of Vivienne Muller's interpretation of Lacan's mirror stage in Marxist terms, writes that "...society, carrying its ideological imperatives, admits the subject into a culture compelling it to recognise and relate to the various images of the culture's identity" (56). It's a capitalism driven cycle where, first, a vacuum of love and happiness- that comes naturally from human relationships- is caused due to the sense of alienation one feels in today's urban corporate culture and then later, this emptiness thus created is compensated by luring people to indulge in inanimate objects offered by the consumerist culture. Tyler succinctly describes this cycle when he says that we are all "slaves with white collars. Advertising has us chasing cars and clothes. Working jobs we hate so that we can buy shit we don't need". WhileFight Club makes the consumer feel like a culprit who if strong willed, can succeed in notgetting subsumed by consumerism, Confessions of a Shopaholic, on the other hand, shows Becky as an innocent victim of the predatory consumer culture, where she is enticed by the mannequins to enter the store and shop. "The mannequins act as sirens luring Becky to her doom as well as a physical embodiment of Becky's faulty inner voice" (Todd 56).

Another difference lies in the ending of the two movies. Belonging to the genre of romantic comedy, Confessions ends on a fairytale-like note. Luke Brandon's intervention in saving his beloved from her ultimate fall exemplifies Disney's glorified idea of the damsel in distress. Apart from this, another issue worth analysing is the contradiction that lies in putting up the "The Girl in the Green Scarf's Sale and Auction". It is the sales at stores which always put Becky into trouble but at the end, she uses the same trick to help herself swim out of the debt pool. Becky finds her state of bliss but the movie ends up reiterating the consumerist culture.

Fight Club, on the other hand, keeps emphasising on its anti-capitalist and anticonsumeristsentiments. "You are not your job. You are not how much money you have in the bank. You are not the car you drive. You are not the contents of your wallet ..." (Fight Club).

Tyler's habit of splicing pornographic scenes into regular family movies can be seen as indicative of his later activities intended to create disorder and also an effort to not let the audience become passive recipients and accept whatever they are shown or sold (something that the capitalists aim for). "Fight Club" slowly turns into "Project Mayhem" which aims at destructive activities like damaging cars, a corporate art piece, a coffee shop, a computer store and TV antennas. There is no doubt that such activities indeed create agitation and Tyler's ultimate goal of bringing down the headquarters of the major credit companies seems naive and unrealistic.

\section{Conclusion}

One cannot afford to not appreciate the effort this cinematic venture makes in articulating something (capitalism) which seems intangible or ineffable. Moreover, it is not that the disorder does not already exist in the society. It exists but in the form of an organised chaos which is controlled by what Althusser calls Ideological and Repressive State Apparatuses. The already established order of functioning gives us a fake sense of security and order which makes it difficult for us to imagine an equivalent for this familiarity. What then comes out of Tyler's destructive actions is an attempt to expose the concealed chaos. Once the society comes face to face with what it fears (or is made to fear), there would be nothing more to be afraid of. According to Fredric Jameson, it is the "sheer systematicity"- in which "the entire world is suddenly sewn up into a total 
system from which [people think] no one can secede" -that blocks us from imagining a future that stands for an end of capitalism and not an end of the world (91).Tyler's endeavour seems to be that of leaving behind the apparent safety valve, embracing the chaos, and seeing what awaits us at the other end of the spectrum.

\section{References}

[1] Barthes, Roland. (1991). "Soap-powders and Detergents." Mythologies. Translated by Annette Lavers, Noonday Press, 35-37.

[2] Baudrillard, Jean. The Consumer Society: Myths and Structures, edited by Mike Featherstone, SAGE Publications.

[3] Colman, David. (2009). "Calming the Voices that Scream 'Shop!'." The New York Times., www.nytimes.com/2009/02/12/fashion/12SHOPAHOLIC.html

[4] Confessions of a Shopaholic. (2009).Directed by P.J. Hogan, performance by Isla Fisher, TouchstonePictures, Film.

[5] Corbett, James. (1999)."Soap and Anarchy." You do not talk about Fight Club: I am Jack's CompletelyUnauthorized Essay Collection, edited by Read Mercer. (2008), BenBella Books, 5361.

[6] Fight Club. (1999). Directed by David Fincher, performances by Brad Pitt, Edward Norton and HelenaBonham Carter, 20th Century Fox, Film.

[7] Jameson, Fredric. (1998). "'End of Art' or 'End of History'." The Cultural Turn: Selected Writings onthe Postmodern 1983-1998, Verso Books, 73-92.

[8] Muller, Vivienne. (2009). "The Dystopian Mirror and the Female Body." Social Alternatives, vol. 28, 29-34.

[9] O’Guinn, Thomas C., and Ronald J. Faber. (1989) "Compulsive Buying: A Phenomenological Exploration.” Journal of Consumer Research, vol. 16, no. 2, 147-57.

[10] Peñaloza, Lisa, and Michelle Barnhart. (2011) "Living U.S. Capitalism: The Normalization Of Credit/Debt." Journal of Consumer Research, vol. 38, no. 4,743-762. JSTOR. www.jstor.org/stable/10.1086/660116.

[11] Stephen, Ann. (1991). "Selling Soap: Domestic Work and Consumerism." Labour History, no. 61, 57-69. JSTOR. www.jstor.org/stable/27509090.

[12] Todd, Danielle. "The Shopping, Consumer Culture, and Identity.” HOHONU, vol.10, 55-57.

*Corresponding author.

E-mail address: ankitasingh2021@ gmail.com 